OPEN ACCESS

Edited by:

Julia Buck,

University of North Carolina

at Wilmington, United States

Reviewed by:

Jonathan Trevor Vannatta,

Purdue University, United States

David W. Thieltges,

Royal Netherlands Institute for Sea

Research (NIOZ), Netherlands

*Correspondence:

Christian Selbach

christian.selbach@bios.au.dk

Specialty section:

This article was submitted to Behavioral and Evolutionary Ecology, a section of the journal

Frontiers in Ecology and Evolution

Received: 03 June 2020

Accepted: 20 October 2020

Published: 10 November 2020

Citation:

Selbach $C$ and Mouritsen KN (2020) Mussel Shutdown: Does the Fear of Trematodes Regulate the Functioning of Filter Feeders

in Coastal Ecosystems?

Front. Ecol. Evol. 8:569319. doi: $10.3389 /$ fevo.2020.569319

\section{Mussel Shutdown: Does the Fear of Trematodes Regulate the Functioning of Filter Feeders in Coastal Ecosystems?}

\author{
Christian Selbach* and Kim N. Mouritsen \\ Department of Biology, Aquatic Biology, Aarhus University, Aarhus, Denmark
}

Parasite infections have negative impacts on their hosts. Accordingly, many organisms try to detect and avoid infective parasite stages, leading to changes in host behavior or physiology. Such non-consumptive effects (NCEs) on host traits can have cascading impacts on whole ecosystems but remain largely overlooked. Here, we discuss the potential impacts of the presence of free-living trematode stages on blue mussels Mytilus edulis, an important ecosystem engineer in coastal habitats, and highlight the ecological implications of these interactions. Specifically, we discuss how parasite avoidance behavior can regulate the filtration activity of these bivalves in coastal ecosystems and show how even moderate changes in mussel behavior can lead to farreaching shifts in energy flow. Such processes might be further amplified under future climate change developments, since both parasite abundance and biotic productivity are highly temperature dependent. Overall, we hypothesize that, in addition to their more evident consumptive impacts, trematodes act as cryptic ecosystem engineers by shaping bivalve filtration processes via NCEs. Due to our still very limited understanding of these parasite-mediated processes, we outline key questions for future research directions. We hope this perspective will help encourage new efforts to empirically investigate these fascinating processes that can be crucial regulatory forces in complex ecological systems.

Keywords: Mytilus edulis, ecosystem engineer, non-consumptive effects, ecology of fear, parasite, trematode

\section{INTRODUCTION}

Fear shapes ecological landscapes. Animals have long been known to sense and avoid potential predators via a range of behavioral, physiological, and morphological adaptations (Werner and Peacor, 2003; Creel and Christianson, 2008). Even plants have been shown to employ sophisticated perceptual abilities to detect the presence of herbivores and can induce defense mechanisms, such as leaf closure, under perceived danger (Mescher and De Moraes, 2015). Such risk effects or nonconsumptive effects (NCEs) have far-reaching impacts on the interaction between organisms and the structure of whole ecosystems, which can even exceed the direct effects of predation (Ripple and Beschta, 2004; Preisser et al., 2005; Creel and Christianson, 2008; Suraci et al., 2016). For example, the waterborne risk cues released by a crab predator change the grazing behavior of snail species in intertidal rocky shores, which in turn controls the abundance and distribution of brown algae 
and barnacles, and thus shapes the whole community dynamics of these coastal systems (Trussell et al., 2003). Collectively, these ecological consequences of predator avoidance are referred to as the "ecology of fear" (Brown et al., 1999; Zanette and Clinchy, 2019).

Just like predators, parasites can have a strong negative impact on their host's fitness, i.e., survival and reproductive success (Bush and Clayton, 2018), and just like prey fear and try to avoid their predators, the risk of encountering parasites can induce "fear" or "disgust" in free-living organisms (Buck et al., 2018; Weinstein et al., 2018). Accordingly, hosts have developed a range of parasite and pathogen avoidance strategies and mechanisms, ranging from avoiding interaction with infected conspecifics to evading parasite transmission stages directly when they can be detected, or indirectly via cues related to infection risks, such as potentially contaminated food items (Behringer et al., 2018; Buck et al., 2018). How individuals can detect and avoid parasites depends on a wide variety of factors, including the organism's habitat and life style as well as the parasite's transmission and host finding strategies (see Behringer et al., 2018). The ecological impacts of NCEs of parasites have been shown to be comparable to the far-reaching effects of anti-predator responses (Rohr et al., 2009). However, while the ecology of fear is an integral element of our understanding of predator-prey interactions, host-parasite interactions have so far received considerably less attention in this regard. Although empirical evidence of parasite avoidance behaviors is accumulating, our understanding of these interactions is still very limited and needs to include more ecologically important host-parasite systems, in particular from aquatic environments (Behringer et al., 2018).

In coastal marine communities, bivalves often act as ecosystem engineers, i.e., they modulate the availability of resources in an ecosystem (Jones et al., 1994). Blue mussels (Mytilus edulis) form extensive mussel beds along Atlantic coastlines, often covering areas of up to hundreds of hectares. These mussel populations play central ecological roles such as filtering out large amounts of organic matter and creating biogenic reefs, on which a range of organisms depend for shelter, substrate, and foraging (Ragnarsson and Raffaelli, 1999; Bertness, 2007; Commito et al., 2008; Larsson et al., 2017). The two trematode species Himasthla elongata and Renicola roscovita utilize $M$. edulis as a host. Both parasites share similar life cycles and require the infected mussel to be eaten by shorebirds to mature (Figure 1A). Blue mussels become infected via free-swimming dispersal stages, the cercariae, that are emitted from the common periwinkle snail Littorina littorea and encyst as metacercariae in mussel tissue (Werding, 1969; Figure 1B). Trophically transmitted parasites often directly affect their host's behavior or physiology to facilitate transmission. In the case of $H$. elongata, metacercariae predominantly infect the mussel's foot and mantle tissue, reducing byssal thread production, which likely increases the risk of dislodgement and predation (Lauckner, 1983). Renicola roscovita encyst mainly in the gills and palps, decreasing the mussel's filtration and growth abilities (Thieltges, 2006; Stier et al., 2015). Moreover, trematode infections induce pathological responses in $M$. edulis, e.g., a decreased heart rate, highlighting that infected individuals are at an energetic disadvantage

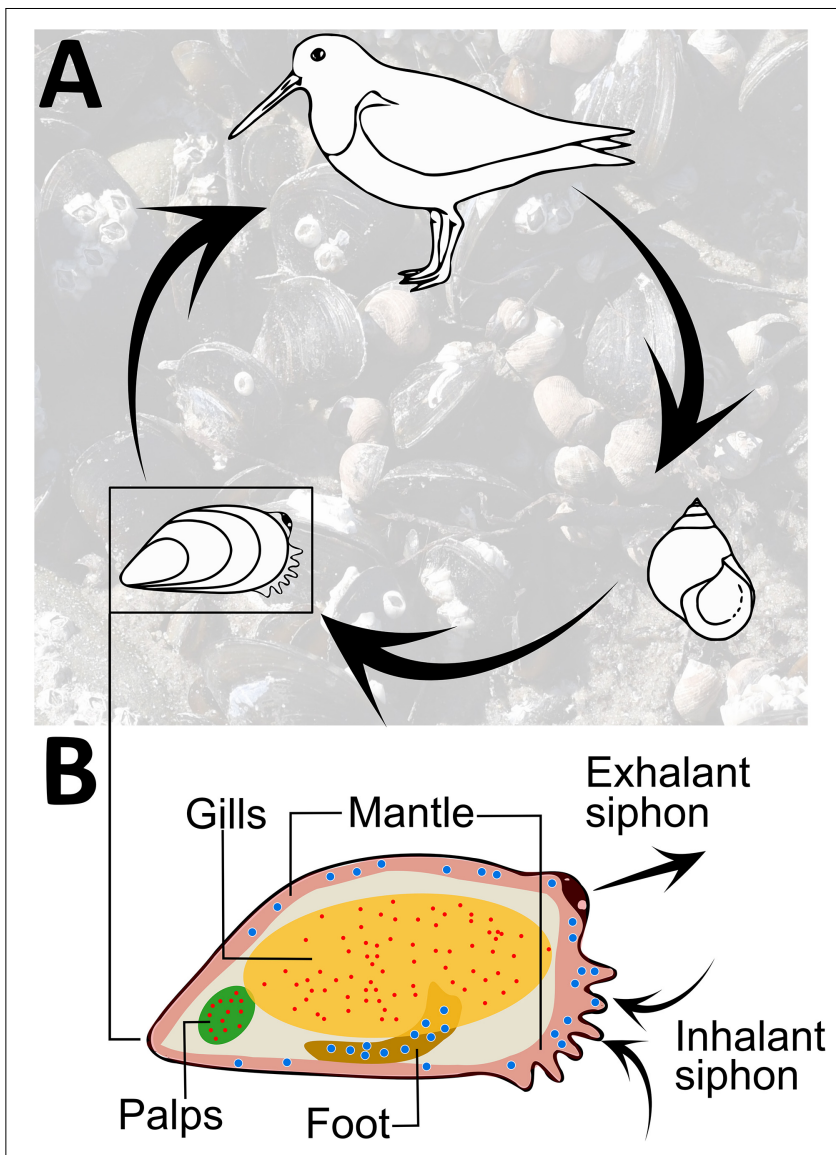

FIGURE 1 | (A) Schematic life cycle of the trematode species Himasthla elongata and Renicola roscovita that utilize seabirds as final hosts, and periwinkle snails Littorina littorea and blue mussels Mytilus edulis as first and second intermediate hosts, respectively. Background photo: M. edulis and L. littorea in a mussel bed during low tide. (B) Schematic drawing of the tissues of $M$. edulis that metacercariae of $H$. elongata (large blue dots) and $R$. roscovita (small red dots) typically parasitize; arrows indicate water flow during the mussel's filtration activity. All organisms not drawn to scale.

compared to uninfected conspecifics (Bakhmet et al., 2017). Overall, trematode infections come at immense fitness costs to the mussels, and they should benefit from avoiding the infective cercariae.

While more motile hosts groups, such as tadpoles, can evade infectious trematode cercariae via increased swimming activities (Rohr et al., 2009), semi-sessile mussels cannot rely on such escape tactics. Instead, bivalves (cockles) have been reported to strongly react to trematodes in the water by contracting their inhalant siphon and expelling cercariae that were inhaled (Jensen et al., 1999). In laboratory trials, we were able to repeatedly observe a similar behavior in M. edulis. When exposed to water containing cercariae of $H$. elongata, mussels rapidly contracted their siphons, before closing their shells completely after a few minutes (Figure 2). Such changes in behavior and withdrawing into their shells is a common response to avoid imminent danger from parasites or predators (Dzierżyńska-Białończyk et al., 2019). Although intertidal organisms such as blue mussels are well 

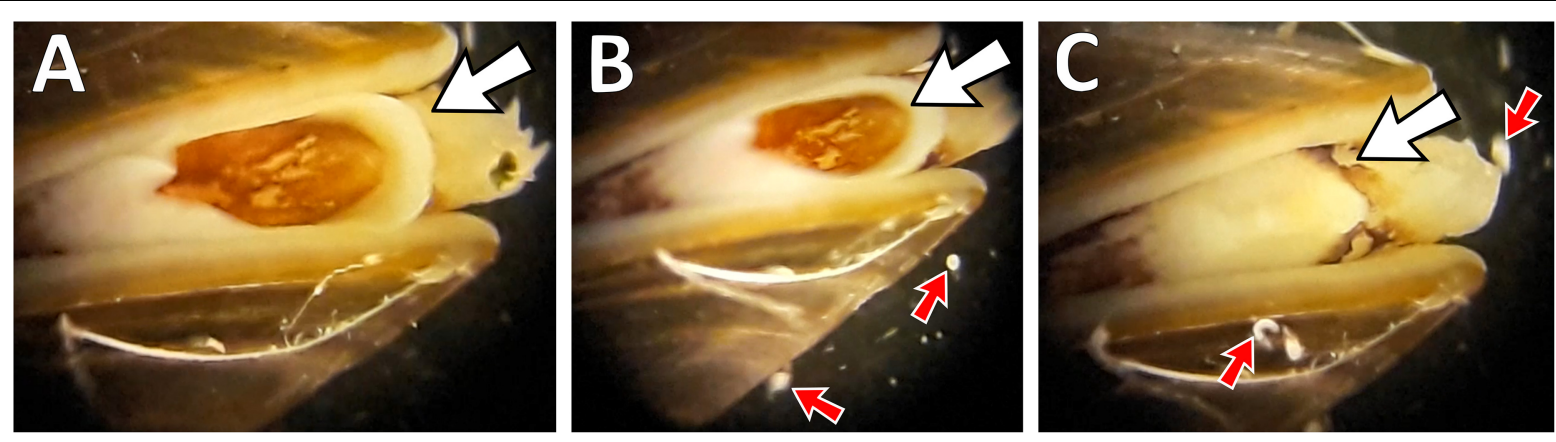

FIGURE 2 | Photo series of Mytilus edulis reacting to Himasthla elongata cercariae in the water observed under laboratory conditions. (A) Mussel filtering with exhalant siphon (white arrow) wide open. (B) Cercariae of $H$. elongata (small red arrows) swarming around the mussel. (C) Mussel retracting exhalant siphon and ceasing filtration activity.

adapted to rapidly changing environmental conditions and can withstand prolonged periods out of the water, a parasite-induced shell closing prevents mussels from feeding and ventilating when submerged, thereby reducing crucial energy uptake and metabolism (Gosling, 2003). At the same time, such a shutdown of mussel activity results in a reduction in their ability to perform a vital ecosystem function, the removal of organic matter from the pelagic environment. Parasite-NCEs could therefore have severe ecological implications for coastal systems, in particular, under warm conditions when both parasite emission and algal growth peak. However, to what extent these processes take place and could shape ecosystems remains completely overlooked.

Here, we discuss these fundamental interactions and highlight their potential ecological implications based on a musseltrematode model system. Specifically, our key questions are, (i) how can trematode avoidance behavior impact the filtration ability of bivalves in coastal habitats, and what are the potential ecological consequences, and (ii) since both parasite presence and biotic productivity are temperature dependent, which future developments can be expected under current climate change scenarios? Overall, we hypothesize that trematodes act as cryptic ecosystem engineers by shaping bivalve filtration via NCEs, in addition to their more obvious infection costs. Due to our very limited understanding of these processes, we outline key questions for future research directions.

\section{QUANTIFYING THE ECOLOGICAL COSTS OF MUSSEL SHUTDOWN}

Along the North Sea coast, blue mussels form dense beds with thousands of individuals per square meter that have the capacity to filter the water column several times a day and significantly reduce the density of microalgae and smaller mesozooplankton organisms (Prins and Smaal, 1994; Laursen et al., 2010; Dolmer and Stenalt, 2010). Along these coastlines, periwinkle snails from which the infective parasite cercariae emerge live in high density within these blue mussel beds, often grazing directly on and around the mussels (Lauckner, 1984; personal observation; Figure 1A). Prevalence of infection in these snail populations shows large temporal and spatial variation but can locally be high and reach more than 50\% (Werding, 1969; Lauckner, 1984; Mouritsen, 2017; personal observation). During summer, a single infected snail can release hundreds of cercariae within a few hours (Thieltges and Rick, 2006; personal observation), resulting in large numbers of these infective transmission stages swarming in the water column in search of suitable target hosts (see Morley, 2012). Under such conditions, mussels will regularly come into contact with large numbers of cercariae and be prompted to close their shells to avoid infection with the parasites.

In the western Limfjord, Denmark, a $12,000 \mathrm{~m}^{2}$ intertidal mussel bed with average densities of 1,000 individuals $\mathrm{m}^{-2}$ was shown to clear approximately $37,000 \mathrm{~m}^{3}$ of water during each tidal cycle (Vismann et al., 2016). After corrections for potential overestimations, the authors conclude that the bivalve bed cleared the available water column in the shallow intertidal zone close to 1 time during a tidal cycle. Since these clearance rates were assessed based on field measurements during the summer months when trematode prevalence and transmission dynamics peak, parasiteinduced closure of $M$. edulis and a reduction of their filtration activity are likely an integral but overlooked part of this equation. Although we still lack data to accurately quantify the reduction in mussel clearance rates as a result of parasite avoidance, even moderate NCEs of parasites could translate into strong impacts at the ecosystem level that should be tested in the future.

\section{PARASITES AS CRYPTIC ECOSYSTEM ENGINEERS?}

Parasites themselves have been recognized as important ecosystem engineers that modulate the availability of resources to other species via biotic or abiotic changes (Thomas et al., 1999; Pascal et al., 2020). Yet, these estimations of the ecological functions of parasitism are typically only based on post-infection, i.e., consumptive, effects of parasites, which likely grossly underestimates the full impact of these organisms on their environment. In a complex ecosystem, both consumptive and NCEs will take place simultaneously, i.e., a host can already have acquired a number of parasites while trying to avoid further 
infections. In the case of $M$. edulis, established infections with $R$. roscovita in the gills and palps impair the mussel's filtration ability (Stier et al., 2015), while the presence of cercariae in the environment and subsequent closure of mussels can further limit this activity (see Figure 2). This can have potentially interacting or cascading effects on the hosts and their ability to provide valuable ecological functions. Since mussels themselves are important food items to a wide range of keystone predators in the habitat (e.g., crabs and seabirds), the parasite-mediated lower energy uptake and growth rates can be expected to influence the energy flow in coastal systems.

Accordingly, the largely unknown NCEs of parasites are likely playing an important yet still hidden role in the function of these organisms as ecosystem engineers. Moreover, just like NCEs of predators can outweigh the direct ecological impacts of predation (Preisser et al., 2005; Creel and Christianson, 2008; Suraci et al., 2016), this is potentially also true for parasites and pathogens. In the case of blue mussel filtration, the consumptive impact of parasites on the host increases with infection intensity (Thieltges, 2006), i.e., it will only begin to show over time as individual mussels acquire substantial amounts of metacercariae in their tissue. The effects of parasite avoidance behavior, on the other hand, are likely to show immediate effects once significant numbers of trematode cercariae are present in the water and will also affect unparasitized individuals. Overall, both costs of infection and NCEs of parasites have shaped the long coevolution of intricate host-parasite systems and their interaction (Poulin, 2007; Behringer et al., 2018). For instance, it has been suggested that circadian rhythms of Mytilus filtration and the mussels' tendency of to keep their valves closed during daytime has evolved as an anti-predator response (Gnyubkin, 2010). Since cercarial activity in the water typically peaks during daytime, this behavioral adaptation and the ecological implications are very likely shaped by parasite NCEs. To understand the "full" ecosystem engineering potential of host-parasite systems, we must study all effects of parasites on their hosts, and the potential interactions between these factors. This will also advance our understanding of the role of host-parasite systems in changing environments.

\section{TURBID TIMES AHEAD?}

Global climate change and ocean warming will have severe and lasting impacts on free-living and parasitic marine biota (Harvell et al., 2002; Marcogliese, 2008; Smale et al., 2019). Although the response of parasites to climate change is complex (see Marcogliese, 2016), the transmission dynamics of trematodes are expected to increase in warmer environments, since higher temperatures can provide favorable conditions for both intermediate and final hosts, allowing longer host-parasite transmission windows (Mas-Coma et al., 2009), and increase the release of infective cercariae into the water (Poulin, 2006; Poulin and Mouritsen, 2006; Studer et al., 2010). Higher levels of trematode infection in bivalves are typically associated with warm water temperatures, e.g., in shallow tidal pools and during summer, indicating that these parasites might benefit from an overall increase in temperature (Thieltges and Rick, 2006). Accordingly, we would expect both the consumptive as well as the NCEs of trematodes on blue mussels to intensify under predicted global warming developments.

At the same time, climate change is altering the distribution and potentially increasing the rate of primary production in the world's oceans (Rabalais et al., 2009; Brown et al., 2010). Under such a scenario, the combination of higher primary production and the parasite-induced reduced filtration activity of bivalves could have implications for the nutrient cycling and food webs in coastal ecosystems. Bivalves might not be able to adequately filter and remove the higher concentration of organic matter from the water column in coastal areas, resulting in increased oxygen depletion and water turbidity, which have been shown for other host-parasite systems (Sánchez et al., 2016).

Under changing climate conditions, even small changes in NCE dynamics could potentially lead to larger cascading impacts, in particular during the warmer summer months. Recent studies have highlighted how trematodes can act as potent ecological engineers and alter the structure and function of communities in intertidal systems under increasing temperatures (Mouritsen et al., 2018). To be able to understand and ultimately predict how ecological systems will react to changing environmental conditions, we therefore need to include the dynamics of parasite NCEs into our assessments.

\section{OPEN QUESTIONS AND FUTURE RESEARCH}

Due to our limited knowledge of these important inter-specific interactions, many elements of NCEs on blue mussels remain speculative and will require further investigation. For instance, the exact mechanisms by which bivalves can detect swarming trematode cercariae in the water remain unclear. Blue mussels have been shown to detect and actively react to volatile chemical cues of potential predators in various ways, e.g., by exhibiting lower rates of respiration and activity or seeking refuge in the mussel bed structure (Reimer et al., 1995; Reimer and Tedengren, 1997). Additionally, bivalves and other organisms are capable of sensing and responding to alarm cues from conspecifics that face parasites or predators (Poulin et al., 1999; Kobak and Ryńska, 2014; Dzierżyńska-Białończyk et al., 2019). It should be tested, if mussels are able to react to parasite-induced chemical cues, or if parasite-avoidance behavior is triggered by physical contact with cercariae. Moreover, it is unknown if the mussels' trematode-avoidance strategies constitute speciesspecific reactions or a generalized response. Since the cercariae of $H$. elongata and $R$. roscovita infect different target tissues and show different infection pathways into their host, they might trigger different parasite avoidance responses. Furthermore, the possible interactions of consumptive and NCEs of parasites on their hosts remain unclear. For example, are already infected mussels more likely to show parasite avoidance behaviors compared to naïve conspecifics, i.e., can mussels learn to avoid parasites (see Behringer et al., 2018)? In addition to $H$. elongata and $R$. roscovita, other trematode species, such as 
Proctoeces maculatus, utilize Mytilus spp. as a first intermediate host, and as parasitic castrators completely eliminate host fitness (Lauckner, 1983; Buck et al., 2018). It should be expected that the anti-parasite responses of an organism are stronger the higher the fitness costs associated with an infection. Blue mussels offer an attractive model to explore these interactions, due to their role as host to a range of trematodes and other parasites.

In order to assess the ecological impacts of a parasite-induced mussel shutdown, experimental approaches will need to quantify how long mussels close upon encountering cercariae and how this affects clearance and filtration rates under varying conditions, e.g., food availability or host nutritional status (see Hutchings et al., 2000). Ultimately, it remains to be explored to what extent a parasite-mediated reduction in filtration activity translates into changes in nutrient and energy cycling in coastal ecosystems, and how this affects other organisms in coastal habitats. For example, could other organisms consume the organic matter left by mussels, and could parasitism therefore expand a niche for these species? In addition to changes in filtration activity, other impacts of parasite-avoidance behaviors should be explored, such as changes in migration and mussel bed aggregation under perceived threats, similar to behavioral responses of predatorexposed M. edulis (Reimer and Tedengren, 1997). Ecological niche shifts due to behavioral and morphological changes have so far been described as a consequence of consumptive effects of trematode infections (e.g., Miura et al., 2006), and it is feasible that NCEs of parasite could have similar impacts. Finally, with regard to future climate changes, a central question is how the dynamics of NCEs of parasites will be affected by changing environmental conditions. In particular, it remains to be tested, if and to what extent changes in water temperature, salinity or resource availability might modulate the mussels' avoidance response to infective parasite stages, and how these processes will impact bivalves and their central ecological functions.

Overall, this range of open questions highlights the possibilities for research projects to answer fundamental ecological questions, using a wide-spread, accessible and relevant mussel-trematode model system for a wide variety of field and laboratory studies.

\section{CONCLUSION}

Fear of parasites can shape and moderate organismic interactions and ecological systems. Although we currently still lack data to quantify the exact amount by which NCEs of parasitism do so for most host-parasite groups, there is mounting reason to expect that this is not different from the "ecology of fear" that regulates predator-prey interactions.

\section{REFERENCES}

Bakhmet, I., Nikolaev, K., and Levakin, I. (2017). Effect of infection with metacercariae of Himasthla elongata (Trematoda: Echinostomatidae) on cardiac activity and growth rate in blue mussels (Mytilus edulis) in situ. J. Sea Res. 123, 51-54.

Behringer, D. C., Karvonen, A., and Bojko, J. (2018). Parasite avoidance behaviours in aquatic environments. Philos. Trans. R. Soc. B Biol. Sci. 373:20170202. doi: $10.1098 /$ rstb.2017.0202
Especially in the case of organisms that function as central ecosystem engineers, such as mussels and their trematode parasites, we should seek out to test specific hypotheses to shine more light on these fundamental processes. We understand the open research questions raised in our perspective as potential starting points for this.

We believe the mussel-trematode system discussed here presents an attractive model system for exploring the ecological impacts of parasite avoidance to better understand the processes that shape complex ecological systems. Based on other welldocumented cases of parasite and pathogen avoidance and their far-reaching ecological implications, we have no reason to believe that this universal pattern would be different for bivalves and their trematode parasites. Mussels and clams are central ecosystem engineers in many coastal ecosystems and trematodes occur in virtually all aquatic habitats. Therefore, the ecological consequences of NCEs of trematodes on bivalves might be a crucial regulatory force in these habitats that we have long overlooked.

\section{DATA AVAILABILITY STATEMENT}

The original contributions presented in the study are included in the article/supplementary material, further inquiries can be directed to the corresponding author/s.

\section{AUTHOR CONTRIBUTIONS}

CS and KNM conceived and wrote the manuscript. Both authors contributed to the article and approved the submitted version.

\section{FUNDING}

This project has received funding from the European Union's Horizon 2020 Research and Innovation Program under the Marie Skłodowska-Curie grant agreement no. 839635 TPOINT.

\section{ACKNOWLEDGMENTS}

We thank Janet Koprivnikar for inviting us (on behalf of the other editors) to contribute to this special issue. We also thank Robert Poulin for feedback and remarks on an earlier draft of our manuscript, and two reviewers for their constructive and helpful comments.

Bertness, D. M. (2007). Atlantic Shorelines: Natural History and Ecology. Princeton: Princeton University Press.

Brown, C. J., Fulton, E. A., Hobday, A. J., Matear, R. J., Possingham, H. P., Bulman, C., et al. (2010). Effects of climate-driven primary production change on marine food webs: implications for fisheries and conservation. Glob. Chang. Biol. 16, 1194-1212. doi: 10.1111/j.1365-2486.2009.02046.x

Brown, J. S., Laundré, J. W., and Gurung, M. (1999). The ecology of fear: optimal foraging, game theory, and trophic interactions. J. Mammal. 80, 385-399. 
Buck, J. C., Weinstein, S. B., and Young, H. S. (2018). Ecological and evolutionary consequences of parasite avoidance. Trends Ecol. Evol. 33, 619-632. doi: 10. 1016/j.tree.2018.05.001

Bush, S. E., and Clayton, D. H. (2018). Anti-parasite behaviour of birds. Philos. Trans. R. Soc. B Biol. Sci. 373:20170196. doi: 10.1098/rstb.2017.0196

Commito, J. A., Como, S., Grupe, B. M., and Dow, W. E. (2008). Species diversity in the soft-bottom intertidal zone: biogenic structure, sediment, and macrofauna across mussel bed spatial scales. J. Exp. Mar. Bio. Ecol. 366, 70-81. doi: 10.1016/ j.jembe.2008.07.010

Creel, S., and Christianson, D. (2008). Relationships between direct predation and risk effects. Trends Ecol. Evol. 23, 194-201.

Dolmer, P., and Stenalt, E. (2010). The impact of the adult blue mussel (Mytilus edulis) population on settling of conspecific larvae. Aquac. Int. 18, 3-17.

Dzierżyńska-Białończyk, A., Jermacz, Ł, Zielska, J., and Kobak, J. (2019). What scares a mussel? Changes in valve movement pattern as an immediate response of a byssate bivalve to biotic factors. Hydrobiologia 841, 65-77. doi: 10.1007/ s10750-019-04007-0

Gnyubkin, V. F. (2010). The circadian rhythms of valve movements in the mussel Mytilus galloprovincialis. Russ. J. Mar. Biol. 36, 419-428. doi: 10.1134/ S1063074010060039

Gosling, E. (2003). Bivalve Molluscs: Biology, Ecology and Culture. Oxford: Blackwell Publishing.

Harvell, C. D., Mitchell, C. E., Ward, J. R., Altizer, S., Dobson, A. P., Ostfeld, R. S., et al. (2002). Climate warming and disease risks for terrestrial and marine biota. Science 296, 2158-2162. doi: 10.1126/science.1063699

Hutchings, M. R., Kyriazakis, I., Papachristou, T. G., Gordon, I. J., and Jackson, F. (2000). The herbivores' dilemma: trade-offs between nutrition and parasitism in foraging decisions. Oecologia 124, 242-251. doi: 10.1007/s004420000367

Jensen, K. T., Castro, N. F., and Bachelet, G. (1999). Infectivity of Himasthla spp. (Trematoda) in cockle (Cerastoderma edule) spat. J. Mar. Biol. Assoc. 79, 265-271. doi: 10.1017/S0025315498000290

Jones, C. G., Lawton, J. H., and Shachak, M. (1994). Organisms as ecosystem engineers. Oikos 69, 373-386.

Kobak, J., and Ryńska, A. (2014). Environmental factors affecting behavioural responses of an invasive bivalve to conspecific alarm cues. Anim. Behav. 96, 177-186. doi: 10.1016/j.anbehav.2014.08.014

Larsson, J., Lind, E. E., Corell, H., Grahn, M., Smolarz, K., and Lönn, M. (2017). Regional genetic differentiation in the blue mussel from the Baltic Sea area. Estuar. Coast. Shelf Sci. 195, 98-109. doi: 10.1016/j.ecss.2016.06.016

Lauckner, G. (1983). "Diseases of mollusca: bivalvia," in Diseases of Marine Animals, Vol. II, ed. O. Kinne (Hamburg: Biologische Anstalt Helgoland), 477-961.

Lauckner, G. (1984). Impact of trematode parasitism on the fauna of a North Sea tidal flat. Helgoländer Meeresuntersuchungen 37, 185-199. doi: 10.1007/ BF01989303

Laursen, K., Sand Kristensen, P., and Clausen, P. (2010). Assessment of blue mussel Mytilus edulis fisheries and waterbird shellfish-predator management in the Danish Wadden Sea. Ambio 39, 476-485. doi: 10.1007/s13280-0100045-0

Marcogliese, D. J. (2008). The impact of climate change on the parasites and infectious diseases of aquatic animals. Rev. Sci. Tech. 27, 467-484.

Marcogliese, D. J. (2016). The distribution and abundance of parasites in aquatic ecosystems in a changing climate: more than just temperature. Integr. Comp. Biol. 56, 611-619. doi: 10.1093/icb/icw036

Mas-Coma, S., Valero, M. A., and Bargues, M. D. (2009). Climate change effects on trematodiases, with emphasis on zoonotic fascioliasis and schistosomiasis. Vet. Parasitol. 163, 264-280. doi: 10.1016/j.vetpar.2009.03.024

Mescher, M. C., and De Moraes, C. M. (2015). Role of plant sensory perception in plant-animal interactions. J. Exp. Bot. 66, 425-433. doi: 10.1093/jxb/eru414

Miura, O., Kuris, A. M., Torchin, M. E., Hechinger, R. F., and Chiba, S. (2006). Parasites alter host phenotype and may create a new ecological niche for snail hosts. Proc. R. Soc. B Biol. Sci. 273, 1323-1328. doi: 10.1098/rspb.2005.3451

Morley, N. J. (2012). Cercariae (Platyhelminthes: Trematoda) as neglected components of zooplankton communities in freshwater habitats. Hydrobiologia 691, 7-19. doi: 10.1007/s10750-012-1029-9

Mouritsen, K. N. (2017). Periwinkle regulation: parasitism and epibiosis are linked. Mar. Ecol. Prog. Ser. 579, 227-231. doi: 10.3354/meps12277

Mouritsen, K. N., Sørensen, M. M., Poulin, R., and Fredensborg, B. L. (2018). Coastal ecosystems on a tipping point: global warming and parasitism combine to alter community structure and function. Glob. Chang. Biol. 24, 4340-4356. doi: $10.1111 /$ gcb.14312

Pascal, L., Grémare, A., de Montaudouin, X., Deflandre, B., Romero-Ramirez, A., and Maire, O. (2020). Parasitism in ecosystem engineer species: a key factor controlling marine ecosystem functioning. J. Anim. Ecol. 89, 2192-2205. doi: $10.1111 / 1365-2656.13236$

Poulin, R. (2006). Global warming and temperature-mediated increases in cercarial emergence in trematode parasites. Parasitology 132, 143-151.

Poulin, R. (2007). Evolutionary Ecology of Parasites (Second Edition). Oxford: Princeton University Press.

Poulin, R., Marcogliese, D. J., and McLaughlin, J. D. (1999). Skin-penetrating parasites and the release of alarm substances in juvenile rainbow trout. J. Fish Biol. 55, 47-53. doi: 10.1006/jfbi.1999.0970

Poulin, R., and Mouritsen, K. N. (2006). Climate change, parasitism and the structure of intertidal ecosystems. J. Helminthol. 80, 183-191. doi: 10.1079/ joh2006341

Preisser, E. L., Bolnick, D. I., and Benard, M. F. (2005). Scared to death? The effects of intimidation and consumption in predator-prey interactions. Ecology 86, 501-509.

Prins, T. C., and Smaal, A. C. (1994). The role of the blue mussel Mytilus edulis in the cycling of nutrients in the Oosterschelde estuary (The Netherlands). Hydrobiologia 282, 413-429. doi: 10.1007/BF00024645

Rabalais, N. N., Turner, R. E., Díaz, R. J., and Justić, D. (2009). Global change and eutrophication of coastal waters. ICES J. Mar. Sci. 66, 1528-1537. doi: 10.1093/icesjms/fsp047

Ragnarsson, S. Á, and Raffaelli, D. (1999). Effects of the mussel Mytilus edulis L. on the invertebrate fauna of sediments. J. Exp. Mar. Bio. Ecol. 241, 31-43. doi: 10.1016/S0022-0981(99)00063-5

Reimer, O., Olsson, B., and Tedengren, M. (1995). Growth, physiological rates and behaviour of Mytilus edulis exposed to the predator Asterias rubens. Mar. Freshw. Behav. Phyiol. 25, 233-244. doi: 10.1080/1023624950937 8920

Reimer, O., and Tedengren, M. (1997). Predator-induced changes in byssal attachment, aggregation and migration in the blue mussel, Mytilus edulis. Mar. Freshw. Behav. Physiol. 30, 251-266. doi: 10.1080/10236249709379029

Ripple, W. J., and Beschta, R. L. (2004). Wolves and the ecology of fear: can predation risk structure ecosystems? Bioscience 54, 755-766.

Rohr, J. R., Swan, A., Raffel, T. R., and Hudson, P. J. (2009). Parasites, infodisruption, and the ecology of fear. Oecologia 159, 447-454. doi: 10.1007/ s00442-008-1208-6

Sánchez, M. I., Paredes, I., Lebouvier, M., and Green, A. J. (2016). Functional role of native and invasive filter-feeders, and the effect of parasites: learning from hypersaline ecosystems. PLoS One 11:e0161478. doi: 10.1371/journal. pone. 0161478

Smale, D. A., Wernberg, T., Oliver, E. C. J., Thomsen, M., Harvey, B. P., Straub, S. C., et al. (2019). Marine heatwaves threaten global biodiversity and the provision of ecosystem services. Nat. Clim. Chang. 9, 306-312. doi: 10.1038/ s41558-019-0412-1

Stier, T., Drent, J., and Thieltges, D. (2015). Trematode infections reduce clearance rates and condition in blue mussels Mytilus edulis. Mar. Ecol. Prog. Ser. 529, $137-144$.

Studer, A., Thieltges, D., and Poulin, R. (2010). Parasites and global warming: net effects of temperature on an intertidal host-parasite system. Mar. Ecol. Prog. Ser. 415, 11-22. doi: 10.3354/meps08742

Suraci, J. P., Clinchy, M., Dill, L. M., Roberts, D., and Zanette, L. Y. (2016). Fear of large carnivores causes a trophic cascade. Nat. Commun. 7:10698. doi: $10.1038 /$ ncomms 10698

Thieltges, D. W. (2006). Effect of infection by the metacercarial trematode Renicola roscovita on growth in intertidal blue mussel Mytilus edulis. Mar. Ecol. Prog. Ser. 319, 129-134.

Thieltges, D. W., and Rick, J. (2006). Effect of temperature on emergence, survival and infectivity of cercariae of the marine trematode Renicola roscovita (Digenea: Renicolidae). Dis. Aquat. Organ. 73, 63-68.

Thomas, F., Poulin, R., de Meeus, T., Guegan, J.-F., and Renaud, F. (1999). Parasites and ecosystem engineering: what roles could they play? Oikos 84, 167-171. doi: $10.2307 / 3546879$

Trussell, G. C., Ewanchuk, P. J., and Bertness, M. D. (2003). Trait-mediated effects in rocky intertidal food chains: predator risk cues alter prey feeding rates. Ecology 84, 629-640. 
Vismann, B., Wejlemann Holm, M., Davids, J., Dolmer, P., Pedersen, M., Blanda, E., et al. (2016). Field clearance of an intertidal bivalve bed: relative significance of the co-occurring blue mussel Mytilus edulis and Pacific oyster Crassostrea gigas. Aquat. Biol. 25, 107-119. doi: 10.3354/ab00661

Weinstein, S. B., Moura, C. W., Mendez, J. F., and Lafferty, K. D. (2018). Fear of feces? Tradeoffs between disease risk and foraging drive animal activity around raccoon latrines. Oikos 127, 927-934. doi: 10.1111/oik.0 4866

Werding, B. (1969). Morphologie, entwicklung und ökologie digener trematodenlarven der strandschnecke Littorina littorea. Mar. Biol. 3, 306-333. doi: 10.1007/ BF00698861

Werner, E. E., and Peacor, S. D. (2003). A review of trait-mediated indirect interactions in ecological communities. Ecology 84, 1083-1100.
Zanette, L. Y., and Clinchy, M. (2019). Ecology of fear. Curr. Biol. 29, 309-313. doi: 10.1016/j.cub.2019.02.042

Conflict of Interest: The authors declare that the research was conducted in the absence of any commercial or financial relationships that could be construed as a potential conflict of interest.

Copyright (c) 2020 Selbach and Mouritsen. This is an open-access article distributed under the terms of the Creative Commons Attribution License (CC BY). The use, distribution or reproduction in other forums is permitted, provided the original author(s) and the copyright owner(s) are credited and that the original publication in this journal is cited, in accordance with accepted academic practice. No use, distribution or reproduction is permitted which does not comply with these terms. 